\title{
Enhancement of the virulence of Aeromonas caviae diarrhoeal strains by serial passages in mice
}

\author{
SYLWIA KRZYMIŃSKA, JOANNA MOKRACKA, MARZENA ŁAGANOWSKA, \\ KRYSTYNA WŁODARCZAK, ELŻBIETA GUSZCZYŃSKA, JOANNA LISZKOWSKA, \\ EWA POPKOWSKA, IZILDA LIMA, IZA LEMAŃSKA and MAŁGORZATA WENDT \\ Department of Microbiology, Experimental Biology Institute, University of Poznań, Poznań 61-701, Poland
}

\begin{abstract}
Thirteen clinical Aeromonas caviae isolates from the faeces of 13 children with mild to severe diarrhoea were tested for enhancement of mouse lethality, adhesion ability, siderophore and cholera toxin cross-reactive (CTC) factor production, by four consecutive passages through mice by intraperitoneal injection of $A$. caviae suspensions. The passaged $A$. caviae strains were re-isolated from monomicrobic cardiac blood samples and inocula were prepared for the next passage. All $A$. caviae isolates possessed the ability to adhere to the mucosal epithelial surface of the rabbit small intestine. Serial passage in mice showed that the virulence of some isolates for mice was increased in terms of percentage mortality and a lowering of the LD50. For some of the isolates, but not all, serial passage appeared to increase siderophore production and adhesion to rabbit small intestinal cells. For the $A$. caviae isolates tested, increased values of the CTC factor were observed after passage. A clear correlation was observed between the lowering of LD50 and the enhancement of CTC factor production after passage in mice. These results indicate that the $A$. caviae isolates possessed virulence factors.
\end{abstract}

\section{Introduction}

The members of the genus Aeromonas are fish and human pathogens, causing fatal haemorrhagic septicaemias in the former, and gastro-enteritis as well as blood, wound and soft-tissue infections in the latter [1]. Mesophilic, motile Aeromonas spp. have been isolated from intestinal and extra-intestinal human infections and from the environment [1-4]. Three types of exotoxin - haemolysins, cytotoxins and the cytotonic enterotoxin cholera toxin cross-reactive (CTC) factor, immunologically related to the cholera toxin - are produced [2,5-10]. This CTC enterotoxin is capable of activating adenylate cyclase, resulting in an increased level of intracellular cAMP. Aeromonas enterotoxin fulfils the criteria for a cytotonic enterotoxin [1]. Aeromonas strains secrete numerous extracellular proteins, including DNAase, RNAase, proteases, elastase, neuraminidase, lipase, phosphatase and fibrinoly$\sin [11,12]$. Aeromonas proteases may enhance virulence, and have a broad specificity for many tissue proteins. The pathological effect of aeromonas pro-

Received 15 Nov. 1999; revised version received 18 Aug. 2000; accepted 25 Aug. 2000.

Corresponding author: Dr K. Wlodarczak. teases is destruction of tissue proteins and loss of local tissue integrity [13].

A. caviae has been considered to be of low pathogenicity or non-enteropathogenic [2, 7, 14]. Gosling [15] showed that only one of 11 strains of $A$. caviae appeared toxigenic. The $A$. caviae strains studied by Janda et al. [16] were avirulent. Janda and Kokka [17] considered $A$. hydrophila and $A$. veronii biotype sobria to be inherently more pathogenic for mice than $A$. caviae.

Several reports have suggested that $A$. caviae strains did not produce any toxic material or that virulence mechanisms were unknown $[5,18,19]$. The enteropathogenicity of $A$. caviae is still questioned [20,21] because conditions for the expression of enterovirulence have not been demonstrated consistently. However, this micro-organism has been recognised increasingly as a primary or secondary invader associated with gastro-enteritis in infants [21,22]. A caviae was rarely encountered as a cause of septicaemia [16].

To understand better the importance of certain virulence factors in the pathogenesis of gastro-enteritis caused by $A$. caviae and to judge whether they are linked to gastro-enteric disease, the influence of 
consecutive passages through mice on mortality, LD50 values, siderophore activity, adherence ability and CTC factor production was determined.

\section{Materials and methods}

\section{Bacterial strains}

Thirteen isolates of $A$. caviae from 13 diarrhoeal faecal specimens, from 13 hospitalised children were studied. They were isolated in the absence of other wellrecognised common bacterial enteropathogens and rotavirus. Each isolate was identified to the species level according to the criteria of other studies $[18,23-$ 31]

Two hundred faecal specimens from 200 healthy controls were analysed for the presence of $A$. caviae. The age range of all hospitalised children and healthy controls was 2 months-2 years.

\section{Mouse model of infection - LD50 studies}

The relative virulence of the $13 \mathrm{~A}$. caviae isolates was evaluated by LD50 studies. The 13 isolates were grown in casamino acids yeast extract medium (CYE), $\mathrm{pH} 7.5$, at $37^{\circ} \mathrm{C}$ in a water bath with shaking for $10 \mathrm{~h}$ [32]. The cultures were centrifuged at $3000 \mathrm{~g}$ for $30 \mathrm{~min}$. The bacterial cells were washed twice with sterile phosphate-buffered saline (PBS), $\mathrm{pH} \mathrm{7.4,} \mathrm{and} \mathrm{resuspended}$ in sterile saline to $6 \times 10^{9} \mathrm{cfu} / \mathrm{ml} \quad\left(\mathrm{A}_{420}=1.2\right)$ (confirmed by plate counts made in duplicate). The relative virulence of the $A$. caviae isolates was evaluated by intraperitoneal injection into 8 -10-weekold Swiss Webster mice, each weighing 18-20 g, of $1 \mathrm{ml}$ of five serial two-fold dilutions of the bacterial suspension. Each isolate was injected into five groups of five mice. Control mice were inoculated with sterile saline. The inoculated mice were observed daily and deaths were recorded up to $72 \mathrm{~h}$. After $72 \mathrm{~h}$, the LD50 was calculated [33].

\section{Passage through mice}

All 13 A. caviae strains were passaged four times in mice by intraperitoneal injection. A. caviae was reisolated from cardiac blood after each passage. Gross inspection for pathological changes was made.

\section{Preparation of culture filtrates}

All isolates were grown in CYE broth at $37^{\circ} \mathrm{C}$ for $10 \mathrm{~h}$ (log phase) in a water bath with shaking. The cultures were then centrifuged at $700 \mathrm{~g}$ for $30 \mathrm{~min}$. The supernates were sterilised by filtration through 0.22 $\mu \mathrm{m}$ pore-size filters (Millipore), stored at $4^{\circ} \mathrm{C}$ and tested in assays within 1 week of preparation $[18,34]$.

\section{Preparation of cell lysates}

Cells of A. caviae isolates cultured on trypticase soy agar plates for $24 \mathrm{~h}$ at $37^{\circ} \mathrm{C}$ were suspended in $0.02 \mathrm{M}$ Tris-buffered saline $(\mathrm{pH} 7.5)$ containing lysozyme 0.5 $\mathrm{mg} / \mathrm{ml}$ and EDTA $37.2 \mathrm{mg} / \mathrm{L}$ at $3 \times 10^{11} \mathrm{cfu} / \mathrm{ml}$. After incubation for $1 \mathrm{~h}$ at $37^{\circ} \mathrm{C}$, the lysates were centrifuged at $700 \mathrm{~g}$ for $30 \mathrm{~min}$. The supernates were sterilised by filtration through $0.22-\mu \mathrm{m}$ filters (Millipore), stored at $4{ }^{\circ} \mathrm{C}$ and tested in assays within 1 week of preparation [35].

\section{CTC factor assay}

Cell-free supernates and lysates from the $13 \mathrm{~A}$. caviae isolates were tested for CTC factor production by the $\mathrm{GM}_{1}$ enzyme-linked immunosorbent assay (ELISA) $[34,35]$. Brieflly, $100 \mu 1$ of monosialoganglioside-GM $\mathrm{GM}_{1}$ (Sigma) $50 \mu \mathrm{g} / \mathrm{ml}$ in carbonate buffer $(\mathrm{pH} 9.6)$ were adsorbed to each well of a round-bottomed microtitration plate (VEB MLW Germany). After incubation for $24 \mathrm{~h}$ at $4{ }^{\circ} \mathrm{C}$ the plates were washed three times with PBS containing $\mathrm{CaCl}_{2} 100 \mathrm{mg} / \mathrm{L}, \quad \mathrm{MgCl}_{2} \cdot 6 \mathrm{H}_{2} \mathrm{O}$ $100 \mathrm{mg} / \mathrm{L}, \mathrm{pH} 7.4$, bovine serum albumin fraction $\mathrm{V}$ (Sigma) $0.1 \%$ and Tween 20 (Sigma) $0.05 \%$ (PBSBSA-Tween). Subsequently $100-\mu 1$ volumes of cholera toxin from Vibrio cholerae O1 (CT; Calbiochem Switzerland) $0.5-500 \mathrm{ng} / \mathrm{ml}$ were added in triplicate to the wells to create a standard curve. CT $(100 \mathrm{ng} / \mathrm{ml})$ was used as a positive control and uninoculated growth medium was used as the negative control. Culture supernates and lysates of $A$. caviae isolates were added in 100- $\mu$ l amounts to the wells; all samples were tested in triplicate. The plates were incubated at room temperature for $24 \mathrm{~h}$. After three washes with PBSBSA-Tween, $100 \mu \mathrm{l}$ of rabbit anti-CT serum (Calbiochem Switzerland) at a dilution of 1 in 640 was added to each well. After incubation for $24 \mathrm{~h}$ at $4^{\circ} \mathrm{C}$, the wells were washed three times with PBS-BSA-Tween; $100 \mu \mathrm{l}$ of protein A-horseradish peroxidase conjugate (Sigma) diluted 1 in 1000 in PBS-BSA-Tween were added to detect bound immunoglobulins. After incubation for $1 \mathrm{~h}$ at $37^{\circ} \mathrm{C}$, the wells were washed three times with PBS-BSA-Tween, and $100 \mu \mathrm{l}$ of the substrate 2,2'azino-bis(3-ethylbenzthiazoline sulphonic acid) 0.1 $\mathrm{mg} / \mathrm{ml}$ in $1 \mathrm{M}$ phosphate-citrate buffer ( $\mathrm{pH}$ 5.0) containing $\mathrm{H}_{2} \mathrm{O}_{2} \quad 0.03 \%$ were added to each well. After incubation for $30 \mathrm{~min}$ at $37^{\circ} \mathrm{C}$, the reaction was stopped by adding $150 \mu \mathrm{l}$ of $1 \mathrm{M} \mathrm{H}_{2} \mathrm{SO}_{4}$ to each well. The results were read as $\mathrm{A}_{410}$ on a Sumal PE2 minireader (Carl Zeiss, Jena). The negative control of CYE broth gave a reading of 0 and wells with an $\mathrm{A}_{410}$ of $\geqslant 0.1$ were recorded as positive. The amount in nanograms of $\mathrm{CT}$ equivalent $/ \mathrm{ml}$ of supernate and cell lysate was estimated from the $\mathrm{CT}$ standard curve.

\section{Siderophore detection and identification}

The 13 A. caviae isolates were grown to stationary phase in Chelex 100 deferrated M9 medium [36]. Cell- 
free culture supernates were examined for siderophore production by the universal chrome azurol assay [37]. The colorimetric tests of Arnow and Csaky were used to detect phenolate and hydroxamate-type siderophores $[38,39]$.

\section{Adhesion assay}

Adherence of $A$. caviae isolates to the epithelium of rabbit small intestine was assayed as described previously [40], but with one slight modification the suspension of $A$. caviae cells was incubated with the intestinal sample for $1 \mathrm{~h}$ at $37^{\circ} \mathrm{C}$. Non-adhering bacteria were removed from the sample by washing four times with Krebs-Ringer solution (KRT). KRT added to the rabbit small intestinal sample was the negative control. The fixed samples were dehydrated through a series of graded ethanol and acetone solutions and critical-point dried. They were coated with gold and examined by scanning electron microscopy (SEM) (Philips type 515). At a magnification of $\times 5000$ the number of bacteria per field was the adherence index.

\section{Electron microscopy for detection of fimbriae [41]}

The bacteria were grown statically in $2 \mathrm{ml}$ of tryptic soy broth (TSB) containing yeast extract $0.6 \%$ for $24 \mathrm{~h}$ at $37^{\circ} \mathrm{C}$. The cultures were centrifuged and the cells were washed twice with PBS, $\mathrm{pH} 7.8$, and suspended in distilled water to $10^{8}-10^{9}$ cells $/ \mathrm{ml}$. Then $10-\mu \mathrm{l}$ volumes of the bacterial suspension, the negative stain (ammonium molybdate 2\%, pH 6.8) and bacitracin $150 \mu \mathrm{g} / \mathrm{ml}$ were mixed and $10 \mu \mathrm{l}$ of the mixture were applied to Formvar 200 mesh copper grids for $1 \mathrm{~min}$. The excess liquid was removed and the grid was allowed to air-dry. The grids were examined with a JEM 1200 IIE transmission electron microscope and photographed.

\section{Cell surface hydrophobicity}

Each $A$. caviae strain to be tested was grown in CYE for $24 \mathrm{~h}$ at $37^{\circ} \mathrm{C}$. The cultures were centrifuged at $3000 \mathrm{~g}$ for $20 \mathrm{~min}$. The pelleted bacterial cells were resuspended in $2 \mathrm{mM}$ sodium phosphate buffer, $\mathrm{pH}$ 6.8, to an $\mathrm{A}_{420}$ value of $1.0\left(10^{8}-10^{9}\right.$ cells $\left./ \mathrm{ml}\right)$.

Salt aggregation test (SAT) [42-44]. Briefly, $30 \mu \mathrm{l}$ of a range of concentrations of $\left(\mathrm{NH}_{4}\right)_{2} \mathrm{SO}_{4}$ in $2 \mathrm{mM}$ sodium phosphate buffer, $\mathrm{pH} 6.8$, from $4 \mathrm{M}$ to $2 \mathrm{M}$ were dispensed into wells of microtration plates and $30 \mu \mathrm{l}$ of the bacterial cell suspension were added to each well. The bacterial suspension in sodium phosphate buffer was used as a negative control. After thorough mixing, the plates were kept at room temperature for $24 \mathrm{~h}$. The lowest concentration of ammonium sulphate that caused bacterial aggregation was recorded as the SAT value.
Bacterial adhesion to hydrocarbons test (BATH) $[42,43]$. For each strain, $4 \mathrm{ml}$ of bacterial suspension were added to each of two 13-mm diameter test tubes, and $4 \mathrm{ml}$ of phosphate buffer were added to each of two other test tubes - control tubes. One $\mathrm{ml}$ of $\mathrm{n}-$ octane (Sigma) was added to both a test tube and a control tube, and $1 \mathrm{ml}$ of $\mathrm{n}$-hexadecane (Sigma) was added to the other assay tube and a control tube. The tubes were placed in a water bath for $10 \mathrm{~min}$ at $37^{\circ} \mathrm{C}$ to equilibrate, were shaken for $15 \mathrm{~s}$ and then incubated for $30 \mathrm{~min}$ at $37^{\circ} \mathrm{C}$. After incubation, the aqueous layer was removed carefully and its $\mathrm{A}_{540}$ value was measured against a control of phosphate buffer. The percentage of partitioning in the hydrocarbon phase was calculated from the formula:

$$
\begin{aligned}
& \mathrm{A}_{540} \quad \begin{array}{c}
\text { (original suspension) } \\
\text { (aqueous suspension }
\end{array} \\
& \frac{\mathrm{A}_{540}}{\mathrm{~A}_{540} \quad \text { (original suspension ) } \times 100} .
\end{aligned}
$$

\section{Results}

In the faecal specimens of 200 healthy controls, $A$. caviae was detected in only one specimen (i.e., $0.5 \%$ ) from a child who had diarrhoea 1 month earlier. $A$. caviae was not present in the faeces of the remaining 199 healthy control children. Thirteen A. caviae isolates from 13 diarrhoeal faecal specimens were studied. The virulence of seven of them was examined after exponential and stationary growth in two culture media at $37^{\circ} \mathrm{C}$.

\section{Cultural conditions for optimum virulence}

The effect of culture conditions on the virulence of the A. caviae isolates for mice was examined by the injection of washed cell suspensions. Cells from exponentially growing cultures in CYE and TSB $\times 2$ caused death - the LD50 being lower for isolates grown in CYE than in TSB $\times 2$. In contrast, cells in the stationary phase of growth, whether from CYE or TSB $\times 2$ cultures, were without effect on mouse mortality or were much reduced in virulence (isolates 378, 380 and 383) (Table 1).

\section{Effects of passage in mice of $A$. caviae isolates upon virulence determinants}

The effects of passage of A. caviae on mortality, siderophore and CTC factor production are presented in Table 2.

Bacteraemia occurred as evidenced by the culture of $A$. caviae from the cardiac blood of each 'squatting' mouse and dead mice after consecutive passages $24 \mathrm{~h}$ after inoculation.

All the $A$. caviae isolates produced siderophores. These were all of the phenolate type and none was of the 
Table 1. Virulence $\left(\mathrm{LD}_{50}\right)$ for mice of seven clinical isolates of $A$. caviae grown in two different culture media and tested at two phases of growth

\begin{tabular}{lccccc}
\hline & \multicolumn{2}{c}{$\begin{array}{c}\text { LD50 }(\log 10) \\
10 \mathrm{~h}^{*}, 37^{\circ} \mathrm{C}\end{array}$} & & \multicolumn{2}{c}{$\begin{array}{c}\text { LD50 }(\log 10) \\
18 \mathrm{~h}^{\dagger}, 37^{\circ} \mathrm{C}\end{array}$} \\
\cline { 2 - 3 } \cline { 5 - 6 } $\begin{array}{l}\text { isolate } \\
\text { no. }\end{array}$ & $\mathrm{CYE}$ & $\mathrm{TSB} \times 2$ & & $\mathrm{CYE}$ & $\mathrm{TSB} \times 2$ \\
\hline 375 & 9.85 & $0^{\ddagger}$ & & 0 & 0 \\
376 & 9.6 & 9.6 & & 0 & 0 \\
378 & 9.5 & 9.7 & & 0 & 9.9 \\
379 & 9.4 & 9.7 & & 0 & 0 \\
380 & 9.3 & 9.3 & & 9.5 & 9.7 \\
383 & 9.4 & 9.6 & & 0 & 9.6 \\
384 & 9.4 & 9.7 & & 0 & 0 \\
\hline
\end{tabular}

CYE, casamino acid yeast extract broth; TSB $\times 2$, glucose-free double-strength tryptic soy broth. ${ }^{*}$ Exponential phase of growth ${ }^{\dagger}$ Stationary phase of growth. "No mortality was observed.

hydroxamate type. Some isolates, e.g., 375, 376 and 380 , produced greater and increasing amounts of siderophore with passage in mice, whereas others, e.g., 383, 384 and 388, continued to be poor siderophore producers despite passage.

CTC factor was not detected by ELISA in either supernates or lysates of isolates 383,385 or 388 . All the other isolates produced CTC factor, greater amounts being detected in supernates than in lysates. Generally, CTC factor levels increased with the number of passages in mice. For some isolates, e.g., 376, 378 and 379, CTC factor was associated with isolates at passage 0, whereas for others, e.g., isolates 375, 377 and 390, CTC factor was only detected after passage. Passage in mice caused some isolates, e.g., 380, 393, 376 and 377 , to cause increased mortality and a decreased LD50 for mice, whereas for other isolates, e.g., 383 and 385, passage did not substantially increase mortality or LD50 for mice.

A correlation was found between CTC factor production, percentage mortality for mice and a decrease in LD50. No such correlation was found between siderophore production and mouse mortality and LD50.

The ability of the 13 isolates of $A$. caviae to adhere to the mucosal epithelial surface of rabbit small intestine was determined by SEM. The results are presented in Table 3 and Fig. 1.

All 13 A. caviae isolates were adherent strains. Five isolates $(375,378,379,380$ and 383) showed enhanced adherence after passage in mice. All of these isolates except no. 383 manifested a correlation between the adherence index and decreased LD50 value, and isolates 375, 378 and 380 manifested enhanced CTC factor production after passage in mice (Table 2). The adherence index of the other isolates did not increase with passage. Isolates 383,385 and 388 that did not produce any CTC factor nor a decrease in LD50 after passage, had a high adherence index, whereas others, e.g., 380, which produced high mortality, high values of the CTC factor and a lower LD50 values after passage in mice, had a low adherence index (Tables 2 and 3). In contrast, isolate 390 had a very high adherence index at passage 0 , yet at this stage did not produce any CTC factor and caused low percentage mortality among mice (Tables 2 and 3).

To evaluate the ability of the $A$. caviae isolates to attach to a surface, the hydrophobicity of the cell surface and the presence of fimbriae was determined, as was the enhancement of these properties by serial passage in mice (Tables 3 and 4). Eight original isolates, and those obtained after their passage in mice, had no fimbriae. Of these, five isolates $(375,378,379$, 380 and 390) were strongly or moderately hydrophobic by SAT and showed a lowering of LD50, and three of them $(375,378$ and 380) gave an enhanced value of the CTC factor after passage in mice. Isolates 383, 386 and 388 were weakly or not hydrophobic by SAT assay, but nos. 383 and 388 were moderately hydrophobic by BATH. These latter two isolates did not show a significant lowering of LD50 and did not produce any CTC factor. Isolate 385 possessed weak hydrophobicity by SAT, but none by BATH, did not show significant lowering of LD50 and did not produce any CTC factor even after passage in mice. Five isolates (nos. 376, 377, 384, 386 and 393) possessed fimbriae and with the exception of no. 386, exhibited weak or moderate positive hydrophobic properties by SAT or BATH assay, or both, produced CTC factor and showed lowering of the LD50.

Only one isolate (377) became strongly hydrophobic by SAT after passage in mice; this isolate possessed fimbriae. Isolates 386 and 393 revealed the presence of fimbriae only after passage in mice. Only three strains became moderately hydrophobic by BATH (n-octane) after passage in mice. There was no correlation observed among the positive results by SAT and BATH (Table 3) and among the results of n-octane and nhexadecane tests by BATH. Six isolates were positive in the BATH test when n-octane was used, but only two isolates were positive when n-hexadecane was used. The lowering of LD50 and the production of the CTC factor did not correlate with hydrophobicity or the presence of fimbriae.

A scanning electron micrograph showing the adherence of some of the A. caviae isolates to the epithelium of rabbit small intestine is shown in Fig. 1.

Gross inspection of mice infected with the clinical isolates of $A$. caviae almost always revealed mice with raised fur, squatting and immobility. Diarrhoea and intestinal fluid accumulation was evidence of $A$. caviae enterotoxigenicity. Post-mortem examination of the alimentary tract from the stomach to the rectum of dead mice made immediately after death revealed distension, swelling, congestion and accumulation of yellow fluid. 
Table 2. Effects of lethal passage in mice of clinical isolates of A. caviae on mortality, siderophore and cytotonic toxin production

\begin{tabular}{|c|c|c|c|c|c|c|}
\hline \multirow{2}{*}{$\begin{array}{l}\text { A. caviae } \\
\text { isolate no. }\end{array}$} & \multirow[b]{2}{*}{ Passage no. } & \multirow{2}{*}{$\begin{array}{l}\text { Mortality } \\
(\%)\end{array}$} & \multirow{2}{*}{$\begin{array}{r}\text { LD50 } \\
\left(\log _{10}\right)\end{array}$} & \multirow{2}{*}{$\begin{array}{l}\text { Siderophore } \\
\text { production }\end{array}$} & \multicolumn{2}{|c|}{$\begin{array}{c}\text { Cytotonic toxin } \\
\text { production* }(\mathrm{ng} / \mathrm{ml})\end{array}$} \\
\hline & & & & & $\mathrm{s}$ & 1 \\
\hline \multirow[t]{5}{*}{375} & $0^{\dagger}$ & 16 & 9.5 & 0.433 & 0 & 0 \\
\hline & 1 & 32 & 9.3 & 0.559 & 0.3 & 0.2 \\
\hline & 2 & 32 & 9.2 & 0.571 & 0.5 & 0.2 \\
\hline & 3 & 32 & 8.8 & 0.717 & 0.4 & 0.2 \\
\hline & 4 & 20 & 9.2 & 0.721 & 0.3 & 0.2 \\
\hline \multirow[t]{5}{*}{376} & 0 & 16 & 9.6 & 0.414 & 0.25 & 0.2 \\
\hline & 1 & 12 & 9.2 & 0.695 & 0.2 & 0.2 \\
\hline & 2 & 16 & 9.1 & 0.661 & 0.2 & 0.2 \\
\hline & 3 & 28 & 9.4 & 0.576 & 0.5 & 0.2 \\
\hline & 4 & 48 & 8.8 & 0.532 & 0.6 & 0.25 \\
\hline \multirow[t]{5}{*}{377} & 0 & 16 & 9.8 & 0.339 & 0 & 0 \\
\hline & 1 & 24 & 9.4 & 0.372 & 0.3 & 0.2 \\
\hline & 2 & 32 & 8.9 & 0.204 & 0.2 & 0.2 \\
\hline & 3 & 32 & 9.2 & 0.335 & 0.7 & 0.2 \\
\hline & 4 & 52 & 8.8 & 0.302 & 0.7 & 0.3 \\
\hline \multirow{5}{*}{378} & 0 & 16 & 9.7 & 0.210 & 0.35 & 0.2 \\
\hline & 1 & 40 & 9.2 & 0.332 & 0.3 & 0.2 \\
\hline & 2 & 28 & 9.0 & 0.338 & 0.7 & 0.2 \\
\hline & 3 & 48 & 8.7 & 0.453 & 0.3 & 0.2 \\
\hline & 4 & 24 & 9.3 & 0.373 & 0.2 & 0.2 \\
\hline 379 & 0 & 20 & 9.9 & 0.203 & 0.35 & 0.2 \\
\hline & 1 & 48 & 8.9 & 0.263 & 0.2 & 0.2 \\
\hline & 2 & 36 & 9.1 & 0.203 & 0.3 & 0.2 \\
\hline & 3 & 20 & 9.6 & 0.261 & 0.3 & 0.2 \\
\hline & 4 & 20 & 9.5 & ND & 0.2 & 0.2 \\
\hline 380 & 0 & 12 & 9.3 & 0.361 & 0.3 & 0.2 \\
\hline & 1 & 48 & 9.2 & 0.394 & 0.2 & 0.3 \\
\hline & 2 & 48 & 9.2 & 0.368 & 0.6 & 0.4 \\
\hline & 3 & 76 & 8.7 & 0.409 & 0.8 & 0.4 \\
\hline & 4 & 76 & 8.0 & 0.520 & 0.8 & 0.5 \\
\hline 383 & 0 & 28 & 9.3 & 0.048 & 0 & 0 \\
\hline & 1 & 24 & 9.6 & 0.095 & 0 & 0 \\
\hline & 2 & 24 & 9.5 & 0.049 & 0 & 0 \\
\hline & 3 & 28 & 9.6 & 0.134 & 0 & 0 \\
\hline & 4 & ND & 9.6 & ND & 0 & 0 \\
\hline 384 & $0^{\dagger}$ & 24 & 9.4 & 0.071 & 0.2 & 0.2 \\
\hline & 1 & 28 & 9.3 & 0.084 & 0.3 & 0.2 \\
\hline & 2 & 40 & 8.8 & 0.096 & 0.6 & 0.3 \\
\hline & 3 & 48 & 9.0 & 0.104 & 0.6 & 0.3 \\
\hline & 4 & 56 & 8.9 & 0.227 & 0.8 & 0.3 \\
\hline 385 & 0 & 12 & 9.7 & 0.243 & 0 & 0 \\
\hline & 1 & 16 & 9.5 & 0.220 & 0 & 0 \\
\hline & 2 & 12 & 9.6 & 0.311 & 0 & 0 \\
\hline & 3 & 16 & 9.3 & 0.288 & 0 & 0 \\
\hline & 4 & 24 & 9.1 & ND & 0 & 0 \\
\hline 386 & 0 & 32 & 9.6 & 0.102 & 0 & 0 \\
\hline & 1 & 32 & 9.6 & 0.133 & 0 & 0 \\
\hline & 2 & 36 & 8.9 & 0.221 & 0.3 & 0.2 \\
\hline & 3 & 40 & 9.3 & 0.253 & 0.2 & 0.2 \\
\hline & 4 & 24 & 9.5 & 0.286 & 0.2 & 0.2 \\
\hline 388 & 0 & 12 & 9.5 & 0.067 & 0 & 0 \\
\hline & 1 & 16 & 9.4 & 0.069 & 0 & 0 \\
\hline & 2 & 24 & 9.6 & 0.129 & 0 & 0 \\
\hline & 3 & 16 & 9.7 & 0.165 & 0 & 0 \\
\hline & 4 & 36 & 9.5 & ND & 0 & 0 \\
\hline 390 & 0 & 12 & 9.5 & 0.273 & 0 & 0 \\
\hline & 1 & 40 & 9.0 & 0.258 & 0.3 & 0.2 \\
\hline & 2 & 44 & 9.0 & 0.196 & 0.3 & 0.2 \\
\hline & 3 & 68 & 8.9 & 0.236 & 0.4 & 0.3 \\
\hline & 4 & 52 & 9.2 & ND & 0.4 & 0.3 \\
\hline 393 & 0 & 44 & 9.5 & 0.273 & 0.2 & 0.2 \\
\hline & 1 & 44 & 8.9 & 0.296 & 0.4 & 0.3 \\
\hline & 2 & 68 & 8.7 & 0.347 & 0.8 & 0.5 \\
\hline & 3 & 52 & 8.6 & 0.378 & 0.9 & 0.6 \\
\hline & 4 & 68 & 8.2 & 0.377 & 0.9 & 0.7 \\
\hline ATCC & 0 & & & & 0 & 0 \\
\hline 15468 & 1 & & & & ND & ND \\
\hline & 2 & & & & ND & ND \\
\hline & 3 & & & & ND & ND \\
\hline & 4 & & & & ND & ND \\
\hline
\end{tabular}

Mortality is given at the percentage of 25 mice that died after intraperitoneal injection; LD50 is expressed in $\log _{10}$; siderophone production is given as the $\mathrm{A}_{630}$ according to the CAS assay method [37].

* Ganglioside $\mathrm{GM}_{1}$ anti-CT ELISA; values are expressed as CT-equivalent units (ng/ml) estimated from the CT-standard curve; s, Activity of culture supernate; 1 , Activity of cell lysate.

The original isolates from hospitalised children (faeces samples).

The enhanced values after first passage and the highest values obtained for mortality, siderophore and toxin production and lowest LD50 values after serial passages are shown in bold; ND, not done. 
Table 3. The effects of lethal passage in mice of clinical isolates of $A$. caviae on the adherence to the rabbit small intestinal surface, presence of fimbriae and cell surface hydrophobicity, in comparison with the lowest value of LD50 and the production of the CTC factor

\begin{tabular}{|c|c|c|c|c|c|c|c|c|c|}
\hline \multirow{3}{*}{$\begin{array}{l}\text { Isolate } \\
\text { no. }\end{array}$} & \multirow{3}{*}{$\begin{array}{c}\text { Passage } \\
\text { no. }\end{array}$} & \multirow{3}{*}{$\begin{array}{l}\text { Adherence } \\
\text { index } \\
(\mathrm{SEM})^{*}\end{array}$} & \multirow{3}{*}{$\begin{array}{l}\text { Fimbriae } \\
\text { (TEM) }\end{array}$} & \multicolumn{3}{|l|}{ Hydrophobicity } & \multirow{3}{*}{$\begin{array}{c}\mathrm{LD} 50 \\
\left(\log _{10}\right)\end{array}$} & \multirow{2}{*}{\multicolumn{2}{|c|}{$\begin{array}{l}\text { CTC factor }{ }^{\dagger} \\
\quad(\mathrm{ng} / \mathrm{ml})\end{array}$}} \\
\hline & & & & \multirow[b]{2}{*}{ SAT } & \multicolumn{2}{|c|}{$\begin{array}{l}\text { BATH } \\
\text { (percent change in absorbance) }\end{array}$} & & & \\
\hline & & & & & n-octane & n-hexadecane & & $\mathrm{S}$ & 1 \\
\hline \multirow[t]{2}{*}{375} & $0^{*}$ & 15 & - & Moderate & Not hydrophobic & Not hydrophobic & 9.5 & 0 & 0 \\
\hline & $3^{\S}$ & 25 & - & Not hydrophobic & Not hydrophobic & Not hydrophobic & 8.8 & 0.4 & 0.2 \\
\hline \multirow[t]{2}{*}{376} & 0 & 31 & + & Moderate & Not hydrophobic & Not hydrophobic & 9.6 & 0.25 & 0.2 \\
\hline & 4 & 7.7 & - & Weak & Not hydrophobic & Not hydrophobic & 8.8 & 0.6 & 0.25 \\
\hline \multirow[t]{2}{*}{377} & 0 & 4.2 & + & Weak & Moderate & Not hydrophobic & 9.8 & 0 & 0 \\
\hline & 4 & 2.8 & + & Strong & Not hydrophobic & Not hydrophobic & 8.8 & 0.7 & 0.3 \\
\hline \multirow[t]{2}{*}{378} & 0 & 10 & - & Strong & Not hydrophobic & Not hydrophobic & 9.7 & 0.35 & 0.2 \\
\hline & 3 & 27 & - & Not hydrophobic & Moderate & Not hydrophobic & 8.7 & 0.3 & 0.2 \\
\hline \multirow[t]{2}{*}{379} & 0 & 2 & - & Moderate & Not hydrophobic & Not hydrophobic & 9.9 & 0.35 & 0.2 \\
\hline & 1 & 22 & - & Moderate & Not hydrophobic & Not hydrophobic & 8.9 & 0.2 & 0.2 \\
\hline \multirow[t]{2}{*}{380} & 0 & 7 & - & Moderate & Not hydrophobic & Not hydrophobic & 9.3 & 0.3 & 0.2 \\
\hline & 4 & 11 & - & Weak & Not hydrophobic & Not hydrophobic & 8.0 & 0.8 & 0.5 \\
\hline \multirow[t]{2}{*}{383} & 0 & 13 & - & Weak & Moderate & Moderate & 9.3 & 0 & 0 \\
\hline & 2 & 22 & - & Weak & Not hydrophobic & Not hydrophobic & 9.5 & 0 & 0 \\
\hline \multirow[t]{2}{*}{384} & 0 & 7 & + & Weak & Moderate & Not hydrophobic & 9.4 & 0.2 & 0.2 \\
\hline & 2 & 4 & - & Not hydrophobic & Not hydrophobic & Moderate & 8.8 & 0.6 & 0.3 \\
\hline \multirow[t]{2}{*}{385} & 0 & 31 & - & Weak & Not hydrophobic & Not hydrophobic & 9.7 & 0 & 0 \\
\hline & 3 & ND & - & Weak & Not hydrophobic & Not hydrophobic & 9.3 & 0 & 0 \\
\hline \multirow[t]{2}{*}{386} & 0 & 10 & - & Not hydrophobic & Not hydrophobic & Not hydrophobic & 9.6 & 0 & 0 \\
\hline & 2 & 6 & + & Not hydrophobic & Not hydrophobic & Not hydrophobic & 8.9 & 0.3 & 0.2 \\
\hline \multirow[t]{2}{*}{388} & 0 & 94 & - & Not hydrophobic & Not hydrophobic & Not hydrophobic & 9.5 & 0 & 0 \\
\hline & 1 & 14 & - & Not hydrophobic & Moderate & Not hydrophobic & 9.4 & 0 & 0 \\
\hline \multirow[t]{2}{*}{390} & 0 & 115 & - & Strong & Not hydrophobic & Not hydrophobic & 9.5 & 0 & 0 \\
\hline & 3 & 38 & - & Not hydrophobic & Moderate & Not hydrophobic & 8.9 & 0.4 & 0.3 \\
\hline \multirow[t]{2}{*}{393} & 0 & 7.4 & - & Weak & Not hydrophobic & Not hydrophobic & 9.5 & 0.2 & 0.2 \\
\hline & 4 & 2.4 & + & Weak & Not hydrophobic & Not hydrophobic & 8.2 & 0.9 & 0.7 \\
\hline
\end{tabular}

* Mean of 30 fields.

${ }^{\dagger}$ CT-equivalent of units $(\mathrm{ng} / \mathrm{ml})$ in culture supernate (s) and cell lysate (l) in $\mathrm{GM}_{1}$ ELISA. ND not done.

The original isolates from hospitalised children (faeces samples).

${ }^{\S}$ Passage number. The LD50 value did not decrease after consecutive passages.

\section{Discussion}

Data about the role of $A$. caviae as an enteropathogen are conflicting [19]. It has been reported that although strains of $A$. sobria and $A$. hydrophila killed mice within $48 \mathrm{~h}$ when injected intraperitoneally, none of 11 A. caviae strains tested killed mice [45]. More recent investigations implicate $A$. caviae as an enteropathogen [5, 22, 46-49]. In the present study, all 13 isolates of A. caviae produced mortality in mice $24-48 \mathrm{~h}$ after injection.

Namdari and Bottone [22] noted that cytotoxin was produced by $A$. caviae in glucose-free TSB $\times 2$ at $16 \mathrm{~h}$ because glucose repressed $A$. caviae cytotoxin production. The higher amounts of amino acids present in CYE medium may stimulate toxin production by $A$. caviae strains. Therefore, in the present study CYE was used for growth of $A$. caviae isolates to be used in the mouse model of infection. It has been shown that culture conditions have a decisive influence on the production of toxins by $A$. caviae.

The cytotonic enterotoxin, CTC factor, was detected in A. caviae supernates and cell lysates and confirmed the enterotoxigenicity of the $A$. caviae isolates. This caused diarrhoea and intestinal fluid accumulation in the mice. Although Shimada et al. [50] demonstrated the production of enterotoxin only by $A$. hydrophila, Potomsky et al. [51] reported that $24 \%$ of $A$. caviae strains reacted with antisera to cholera toxin by ELISA. Cytotonic enterotoxin from Aeromonas spp. isolates caused fluid secretion in Aeromonas-associated diarrhoea [52].

Siderophore production has been suggested as one of the factors determining the virulence of a microorganism $[53,54]$ and was demonstrated under ironlimiting conditions for all $13 \mathrm{~A}$. caviae isolates. However, isolates produced varying amounts of siderophore. Chromosomal genes may control low-level production of siderophores whereas more virulent strains might harbour plasmids encoding for the production of other siderophores [55].

These results indicate that $A$. caviae isolates may employ several strategies for securing host iron, for example, lysis of erythrocytes, digestion of haemoglobin and binding and assimilation of haem.

From this study it was confirmed by SEM that all the A. caviae isolates had the ability to adhere to 

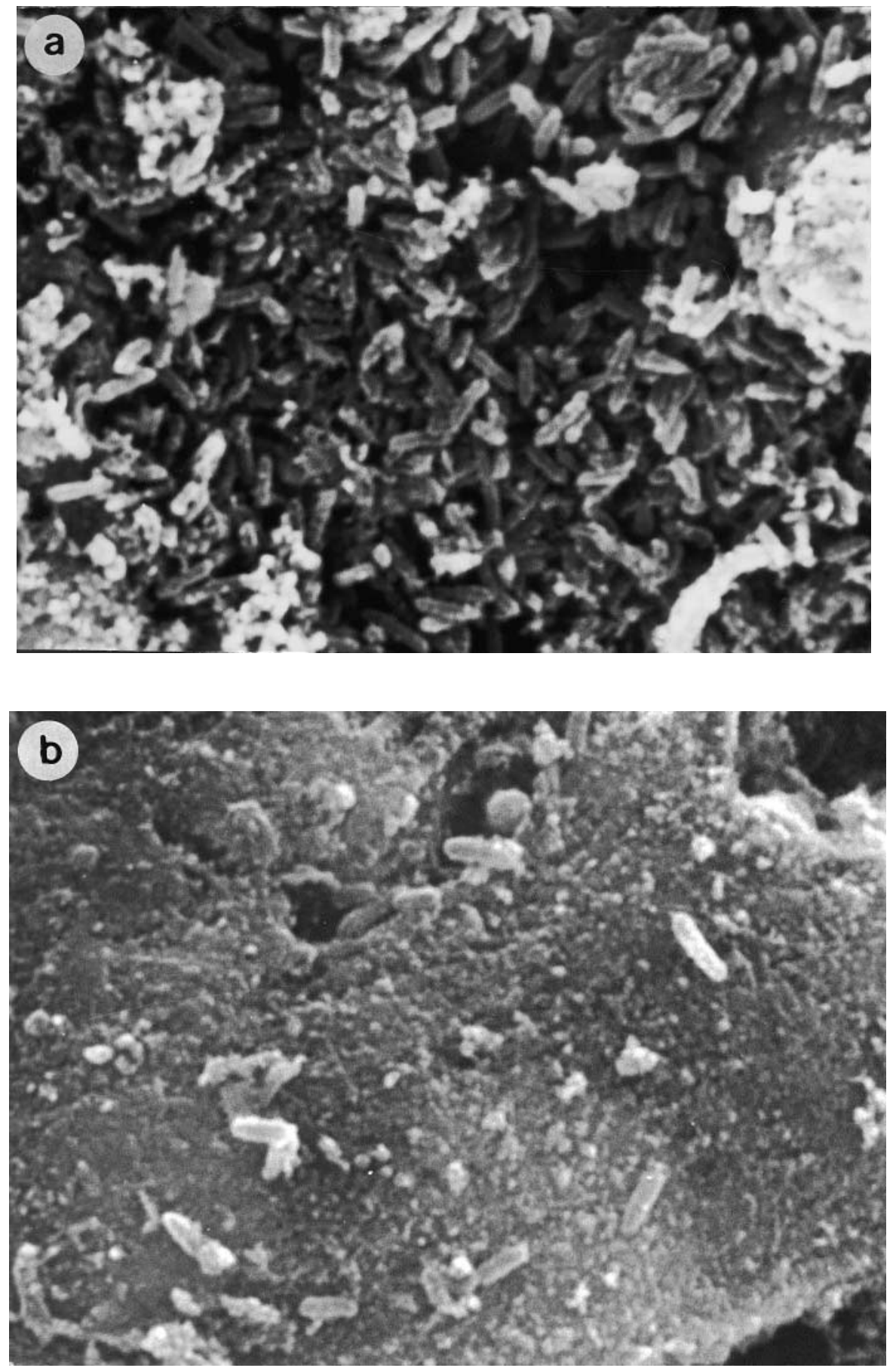

Fig. 1. Scanning electron micrograph showing adherence of $A$. caviae isolates $379,383,385$ and 388 to epithelium of rabbit small intestine: (a) isolate 379 (magnification $\times 3250)$; (b) isolate $383(\times 3250)$; (c) isolate $385(\times 3250)$; (d) isolate $388(\times 7000)$.

epithelium of rabbit small intestine. Bacterial adherence is mediated by adhesin-receptor interactions. Adhesins are surface-attached bacterial proteins and interaction between adhesins and receptors is an important virulence factor for aeromonads [57]. Extracellular matrix components are one such possible attachment site and outer-membrane proteins are another [3, 58].

The fimbrial adhesins play a role during bacterial attachment to the intestinal mucosa in vitro and in vivo
[58]. In the present study, only five $A$. caviae isolates were shown to have fimbriae by TEM. Grewal et al. [59] have shown in vitro that formation of bacterial fimbriae was highly dependent on the presence of bile salts and a growth temperature of $37^{\circ} \mathrm{C}$. Thus, the invivo colonisation by bacteria of the human alimentary tract may be facilitated by fimbriae, because these conditions for the synthesis of fimbriae exist in the alimentary tract. A possible cause of the lack of fimbriae in some isolates of the study was the absence of bile salts in the culture medium. The adhesion of 

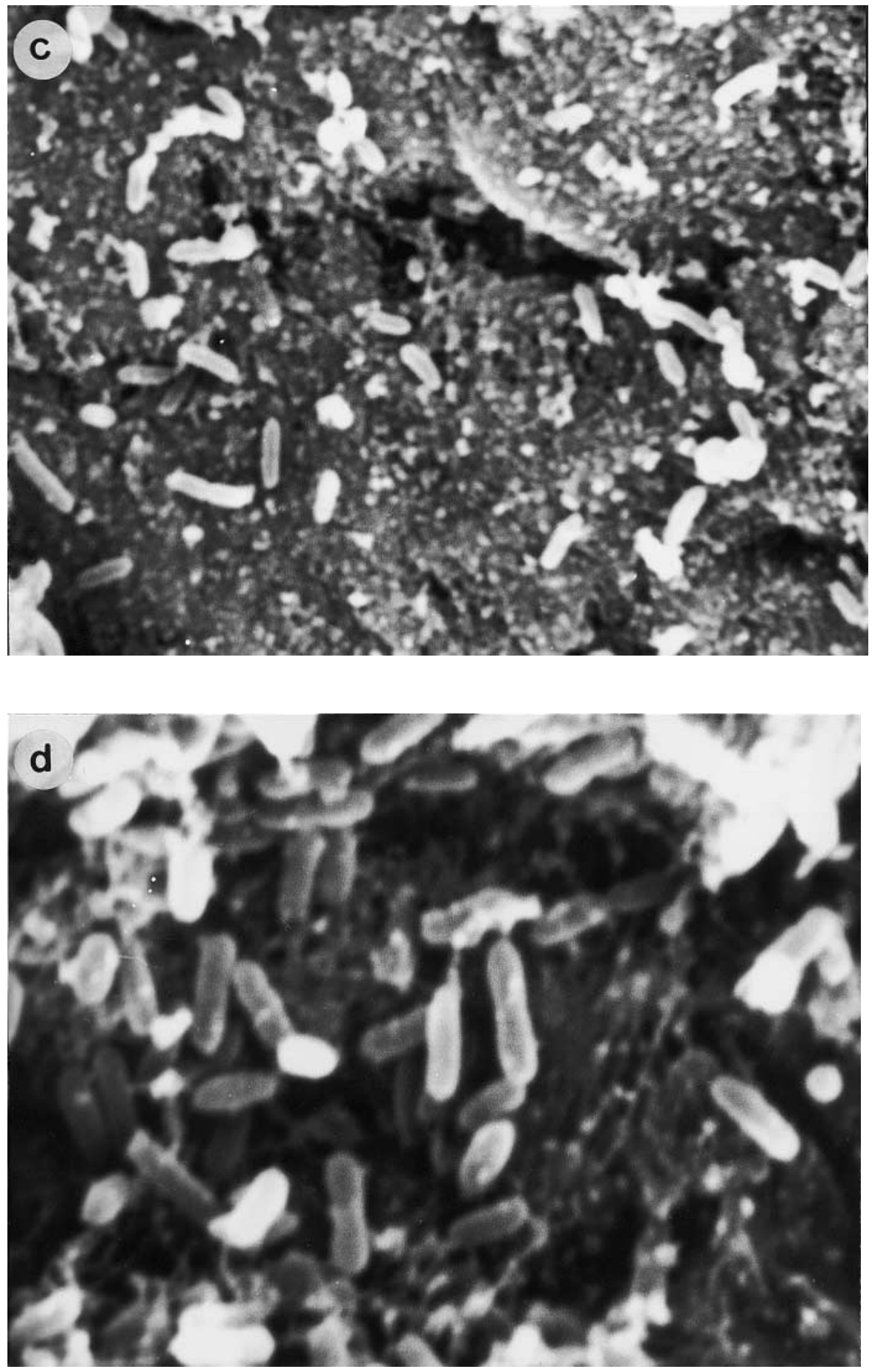

Fig. 1. (Continued).

Table 4. Criteria of hydrophobicity

\begin{tabular}{lcll}
\hline Test & Values & Results & \\
\hline SAT & $0.0-1.0 \mathrm{M}$ & Strong & Positive test \\
& $1.2-2.0 \mathrm{M}$ & Moderate & Positive test \\
& $2.2-4.0 \mathrm{M}$ & Weak & $\ldots$ \\
& $>4.0$ & Not hydrophobic & $\ldots$ \\
BATH & $>50 \%$ & Strong & Positive test \\
& $20-50 \%$ & Moderate & Positive test \\
& $<20 \%$ & Not hydrophobic & $\ldots$ \\
\hline
\end{tabular}

aeromonads to intestinal cells in vivo would be considered a crucial early step in the development of gastro-enteritis. Virulent strains of $A$. caviae are adherent to HEp-2 cells $[20,46]$ and all the $13 A$. caviae diarrhoeal isolates in the present study adhered to the rabbit small intestinal surface, and various values of adherence index were obtained. Dickson and Koohmaraie [42] reported a similar observation. It 
was found that the adherence index did not always increase with passage in mice and an increased adherence index did not always correlate with a decreased LD50 and raised CTC factor production.

Cell surface hydrophobicity has also been identified as an important factor for bacterial attachment to human epithelial cells [42], and in enabling bacteria to interact with animal cells and survive in the host [43]. All isolates tested possessed some degree of hydrophobicity; some showed strong hydrophobicity, whereas others showed moderate or weak hydrophobicity. The SAT method appeared to be suitable for assaying the hydrophobicity of pathogenic $A$. caviae isolates. The BATH n-octane method was more suitable for assaying hydrophobicity than the BATH n-hexadecane method. In the non-fimbriate diarrhoeal isolates examined, hydrophobicity may be the major factor responsible for adherence to epithelial cells.

In conclusion, the data presented in this study indicated that 10 of the 13 diarrhoeal isolates of $A$. caviae produced a factor that was antigenically similar to the cytotonic enterotoxin of $V$. cholerae. The antigenic similarity of the CTC factor to the cholera toxin, intestinal fluid accumulation, and diarrhoeal symptoms in tested mice after intraperitoneal injection of a suspension of $A$. caviae, support the hypothesis that the CTC factor of $A$. caviae strains is a cytotonic enterotoxin. These results advance the role of $A$. caviae as a gastrointestinal pathogen in the mouse model. After passage in mice, a correlation was found in the A. caviae isolates between the ability to increase production of the CTC factor, percentage mortality and lower LD50 values. The data on biological and clinical characteristics confirmed that $A$. caviae can participate in the pathogenesis of diarrhoea in children.

We thank Professor W. Biczysko, head of the Department of Pathological Anatomy at the Poznań Medical Academy, for instructing us in the preparation of slides of rabbit small intestine, and Drs Krystyna Idzikowska and Wojciech Wieczorek from the Laboratory of Electron Microscopy at the University of Poznan for assistance with scanning microscopy. Part of the study was financially supported by the State Committee for Scientific Research: Grant no. GP 20404506 .

\section{References}

1. Ljungh ^, Wadström T. Aeromonas and Plesiomonas as possible causes of diarrhoea. Infection 1985; 13: 169-173.

2. Altwegg M. Aeromonas caviae: an enteric pathogen? Infection 1985; 13: 228-230.

3. Janda JM. Recent advances in the study of the taxonomy, pathogenicity and infectious syndromes associated with the genus Aeromonas. Clin Microbiol Rev 1991; 4: 397-410.

4. Ljungh $\AA$, Wadström T. Aeromonas and Plesiomonas. In: Farthing MJG, Keusch GT (eds) Enteric infection. Mechanisms, manifestations and management. London, Chapman and Hall Medical. 1989: 169-181.

5. Altwegg M. Taxonomy and epidemiology of Aeromonas spp.: the value of new typing methods. ADAG Administration a. Zurich, Druk AG. 1990

6. Hirst TR, Leece R. The phenomenon of toxin secretion by vibrios and aeromonads. Experientia 1991; 47: 429-431.
7. Millership SE, Barer MR, Tabaqchali S. Toxin production by Aeromonas spp. from different sources. J Med Microbiol 1986; 22: $311-314$.

8. Pazzaglia G, Sack RB, Bourgeois AL, Froehlich J, Eckstein J. Diarrhea and intestinal invasiveness of Aeromonas strains in the removable intestinal tie rabbit model. Infect Immun 1990; 58: $1924-1931$.

9. Turnbull PCB, Lee JV, Miliotis MD et al. Enterotoxin production in relation to taxonomic grouping and source of isolation of Aeromonas species. J Clin Microbiol 1984; 19: $175-180$.

10. Ljungh А, Eneroth P, Wadström T. Cytotonic enterotoxin from Aeromonas hydrophila. Toxicon 1982; 20: 787-794.

11. Daily OP, Joseph SW, Coolbaugh JC et al. Association of Aeromonas sobria with human infection. J Clin Microbiol 1981; 13: 769-777.

12. Ljungh А, Wadström T. Preparation of hemolysin from Aeromonas. In: Harshman S (ed) Microbial toxins: tools in enzymology Methods in enzymology 165 San Diego, Academic Press. 1988: 200-203.

13. Gosling PJ. Pathogenic mechanisms. In: Austin B, Altwegg M, Gosling PJ, Joseph SW (eds) The genus Aeromonas. Chichester, John Wiley and Sons. 1996: 245-265.

14. Moyer NP. Clinical significance of Aeromonas species. isolated from patients with diarrhea. J Clin Microbiol 1987; 25: 2044-2048.

15. Gosling PJ. Biochemical characteristics, enterotoxigenicity and susceptibility to antimicrobial agents of clinical isolates of Aeromonas species encountered in western region Saudi Arabia. J Med Microbiol 1986; 22: 51-55.

16. Janda JM, Clark RB, Brenden R. Virulence of Aeromonas species as assessed through mouse lethality studies. Curr Microbiol 1985; 12: 163-167.

17. Janda JM, Kokka RP. The pathogenicity of Aeromonas strains relative to genospecies and phenospecies identification. FEMS Microbiol Lett 1991; 90: 29-34.

18. Honda T, Sato M, Nishimura T, Higashitsutsumi M, Fukai K, Miwatani T. Demonstration of cholera toxin-related factor in cultures of Aeromonas species by enzyme-linked immunosorbent assay. Infect Immun 1985; 50: 322-323.

19. Schiavano GF, Bruscolini F, Albano A, Brandi G. Virulence factors in Aeromonas spp. and their association with gastrointestinal disease. New Microbiol 1998; 21: 23-30.

20. Grey PA, Kirov SM. Adherence to HEp-2 cells and enteropathogenic potential of Aeromonas spp. Epidemiol Infect 1993; 110: 279-287.

21. Pazzaglia G, Sack RB, Salazar E et al. High frequency of coinfecting enteropathogens in Aeromonas-associated diarrhea of hospitalized Peruvian infants. J Clin Microbiol 1991; 29: 1151-1156.

22. Namdari H, Bottone EJ. Cytotoxin and enterotoxin production as factors delineating enteropathogenicity of Aeromonas caviae. J Clin Microbiol 1990; 28: 1796-1798.

23. Abbott SL, Cheung WKW, Kroske-Bystrom S, Malekzadeh T, Janda JM. Identification of Aeromonas strains to the genospecies level in the clinical laboratory. J Clin Microbiol 1992; 30: $1262-1266$.

24. Altwegg M, Steigerwalt AG, Altwegg-Bissig R, Lüthy-Hottenstein J, Brenner DJ. Biochemical identification of Aeromonas genospecies isolated from humans. J Clin Microbiol 1990; 28: 258-264.

25. Carnahan AM, Behram S, Joseph SW. Aerokey II: a flexible key for identifying clinical Aeromonas species. J Clin Microbiol 1991; 29: 2843-2849.

26. Carnahan AM, Joseph SW. Systematic assessment of geographically and clinically diverse Aeromonads. Syst Appl Microbiol 1993; 16: 72-84.

27. Furuwatari C, Kawakami Y, Akahane $\mathrm{T}$ et al. Proposal for an Aeroscheme (modified Aerokey II) for the identification of clinical Aeromonas species. Med Sci Res 1994; 22: 617-619.

28. Hänninen ML, Siitonen A. Distribution of Aeromonas phenospecies and genospecies among strains isolated from water, food or from human clinical samples. Epidemiol Infect 1995; 115: 39-50.

29. Joseph SW, Carnahan AM, Brayton PR et al. Aeromonas jandaei and Aeromonas veronii dual infection of a human wound following aquatic exposure. J Clin Microbiol 1991; 29: 565-569.

30. Kämpfer P, Altwegg M. Numerical classification and identifi- 
cation of Aeromonas genospecies. J Appl Bacteriol 1992; 72: $341-351$.

31. Ogden ID, Miller IG, Watt AJ, Wood L. A comparison of three identification kits for the confirmation of Aeromonas spp. Lett Appl Microbiol 1994; 18: 97-99.

32. Campbell JD, Houston CW. Effect of cultural conditions on the presence of cholera-toxin cross-reactive factor in culture filtrates of Aeromonas hydrophila. Curr Microbiol 1985; 12 $101-106$.

33. Reed LJ, Muench H. A simple method of estimating fifty per cent endpoints. Am J Hyg 1938; 27: 493-497.

34. Vadivelu J, Puthucheary SD, Navaratnam P. Exotoxin profiles of clinical isolates of Aeromonas hydrophila. J Med Microbiol 1991; 34: 363-367.

35. Schultz AJ, McCardell BA. DNA homology and immunological cross-reactivity between Aeromonas hydrophila cytotonic toxin and cholera toxin. J Clin Microbiol 1988; 26: 57-61.

36. Romalde JL, Conchas RF, Torazo AE. Evidence that Yersinia ruckeri possesses a high affinity iron uptake system. FEMS Microbiol Lett 1991; 80: 121-126.

37. Schwyn B, Neilands JB. Universal chemical assay for the detection and determination of siderophores. Anal Biochem 1987; 160: 47-56.

38. Arnow LE. Colorimetric determination of the components of 3,4-dihydro-xyphenylalanine-tyrosine mixtures. J Biol Chem 1937; 118: $531-537$.

39. Cśaky TZ. On the estimation of bound hydroxylamine in biological materials. Acta Chem Scand 1948; 2: 450-454

40. Yamamoto Y, Yokota T. Vibrio cholerae non-01 production of cell-associated hemagglutinins and in vitro adherence to mucus coat and epithelial surface of the villi and lymphoid follicles of human small intestine treated with formalin. J Clin Microbiol 1988; 26: 2018-2024.

41. Knutton S. Electron microscopical methods in adhesion. In: Doyle RJ, Ofek I (eds) Adhesion of microbial pathogens. Methods in enzymology, 253. San Diego Academic Press. 1995: $145-158$

42. Dickson JS, Koohmaraie M. Cell surface charge characteristics and their relationship to bacterial attachment to meat surfaces. Appl Environ Microbiol 1989; 55: 832-836.

43. Lee K-K, Yii K-C. A comparison of three methods for assaying hydrophobicity of pathogenic vibrios. Lett Appl Microbiol 1996; 23: 343-346.

44. Lindahl M, Faris A, Wadstrom T, Hjerten S. A new test based on 'salting out' to measure relative surface hydrophobicity of bacterial cells. Biochim Biophys Acta 1981; 677: 471-476.
45. Janda JM, Oshiro LS, Abbott SL, Duffey PS. Virulence markers of mesophilic Aeromonads: association of the autoagglutination phenomenon with mouse pathogenicity and the presence of a peripheral cell-associated layer. Infect Immun 1987; 55: 3070-3077.

46. Thornley JP, Shaw JG, Gryllos IA, Eley A. Adherence of Aeromonas caviae to human cell lines HEp-2 and Caco-2. $J$ Med Microbiol 1996; 45: 445-451.

47. Namdari H, Bottone EJ. Microbiologic and clinical evidence supporting the role of Aeromonas caviae as a pediatric enteric pathogen. J Clin Microbiol 1990; 28: 837-840.

48. Namdari H, Bottone EJ. Aeromonas caviae: ecologic adaptation in the intestinal tract of infants coupled to adherence and enterotoxin production as factors in enteropathogenicity. Experientia 1991; 47: 434-436.

49. Singh DV, Sanyal SC. Enterotoxicity of clinical and environmental isolates of Aeromonas spp. J Med Microbiol 1992; 36: 269-272.

50. Shimada T, Sakazaki R, Horigome R, Uesaka Y, Niwano K Production of cholera-like enterotoxin by Aeromonas hydrophila. Jpn J Med Sci Biol 1984; 37: 141-144.

51. Potomski J, Burke V, Watson I, Gracey M. Purification of cytotoxic enterotoxin of Aeromonas sobria by use of monoclonal antibodies. J Med Microbiol 1987; 23: 171-177.

52. Chopra AK, Vo TN, Houston CW. Mechanism of action of a cytotonic enterotoxin produced by Aeromonas hydrophila. FEMS Microbiol Lett 1992; 91: 15-20.

53. Żywno SR, Arceneaux JEL, Altwegg M, Byers BR. Siderophore production and DNA hybridization groups of Aeromonas spp. J Clin Microbiol 1992; 30: 619-622.

54. Peterson JW, Baron S. (eds). Bacterial pathogenesis. In: Medical microbiology, 3rd edn. New York, Churchill Livingstone. 1991: 133-146.

55. Hartzen SH, Frimodt-Møller N, Thomsen VF. The antibacterial activity of a siderophore. APMIS 1994; 102: 219-226.

56. Weinberg ED. Patho-ecological implications of microbial acquisition of host iron. Rev Med Microbiol 1998; 9: 171-178.

57. Kirov SM. Adhesion and piliation of Aeromonas spp. Med Microbiol Lett 1993; 2: 274-280.

58. Doig P, Trust TJ. Methodological approaches of assessing microbial binding to extracellular matrix components. $J$ Microbiol Methods 1993; 18: 167-180.

59. Grewal HMS, Valvatne H, Bhan MK, van Dijk L, Gaastra W, Sommerfelt H. A new putative fimbrial colonization factor, CS19, of human enterotoxigenic Escherichia coli. Infect Immun 1997; 65: 507-513. 